\title{
The Development of the Undergraduate Schools of American Universities and Its Influence Upon China's Universities
}

\author{
Zhang Xi-sheng, Zhang Xing-wang \\ Tongji University, Shanghai, China
}

\begin{abstract}
The idea of liberal education and the curricular module are the basic contents to facilitate students by universities in the background of globalization, and the undergraduate school is the carrier or the form of liberal education. The paper presents the implication, characteristics, and the primary form of undergraduate schools; summarizes the process of creation, development, maturity, and steadiness of American undergraduate schools; illustrates the present situation of the development of undergraduate schools in China; and analyzes the problems existing in the development of undergraduate schools. At the end of the paper, it proposes some suggestions and measures for the settlement of the problems existing in the undergraduate schools of the universities in mainland China.
\end{abstract}

Keywords: liberal education, the undergraduate school, Chinese universities, development, influence

\section{Introduction}

Liberal education means that university students of a country would be required to be able to acquire, through a rigorous liberal education curriculum, the shared knowledge that basically includes the system of cultural knowledge and the cultural background knowledge. Its core value is the humanistic accomplishment education. The popularization of liberal education has been obvious in both the United States (U.S.) and the rest of the world since American universities, like Harvard University, started their core curricula. What liberal education counts much is that it can improve students' intelligence structure and aesthetic taste, develop their creativity and adaptability, and promote their character development.

From 1917 to 1919, Columbia University started to offer liberal education courses, which has been regarded as the beginning of modern American liberal education. In the 1940s, liberal education was applied widely in University of Chicago. Led by Hutchinson, liberal education courses were given to the undergraduate students in this university through the four academic years. In 1945, liberal education courses of the liberal society, which were on the basis of lessons drawn from the experiences of the heated discussion over liberal education in the first half of the century in the 1900s and the Chicago debate, were taught in Harvard University. But the student movements in the 1960s had a great impact on American liberal education, and until after the 1970s, especially when liberal education disappeared, almost the whole society started to complain the downgrade of the university teaching. This triggered another heated discussion over liberal education at the end of the 1970s and at the beginning of the 1980s. In 1987, the reform of liberal education in Stanford University

\footnotetext{
Zhang Xi-sheng, Ph.D., associate researcher, Research Institute of Higher Learning, Tongji University.

Zhang Xing-wang, M.A., associate professor, English Department for Non-English Majors, Foreign Languages School, Tongji University.
} 
pushed this discussion to a new climax and liberal education became a hot topic in American politics (Gan, 2007).

Undergraduate schools, where the idea of liberal education was basically applied and where the educational reforms, especially the leading reform by Chicago University in the 1920s and 1930s which were conducted, were a mode of institutional arrangement whereby the American institutions of higher learning organized the undergraduate teaching. This mode is such that all the freshmen will be entered the undergraduate schools and started to study liberal education courses. It has been usually adopted in those research-based universities and become one of the two - the other is the graduate school - core teaching institutes. The liberal education system, which is a sort of teaching and regulatory agency for regulating the academic life of the undergraduates and its system resembles that of a graduate school, is the foundation or a guarantee for the success of other professional studies (Undergraduate School, n.d.).

Science and technology are advancing, the whole world is undergoing dramatic change, the period of job shifting is shortened, and global and local issues are becoming more complicated and delicate. All these have involved the international higher learning in the fierce competition and pushed the reform of the higher learning to a new climax. The mere teaching and learning about the knowledge and skills for the future professions are not so adequate to guarantee the flexibility and adaptability of the graduates when they graduate and enter the true world of occupations and real life. As a result, universities in some countries started to reform the sheltered-content courses and adopt new ideas of liberal education, according the higher priorities to the development of the independence in judgment, discriminability, and critical thinking of the students so that they will have the competence and the globally-mindedness to adapt themselves to the needs of the future global competition.

\section{The Development of American Undergraduate Schools}

\section{The Origin of Undergraduate Schools}

Undergraduate schools originated from the residential colleges in Italy, like University of Bologna and University of Pavia, developed in British universities, like Oxford University and Cambridge University, and ultimately developed further into the full-fledged mode of teaching organization and management in American universities, like Harvard University and Yale University. Such a mode is the basic carrier of liberal education to accommodate to the global challenge (Xu, 2014).

Robert Hutchings, the former president of University of Chicago and an educationalist, published his The Higher Learning in America in 1936. In the article, he pointed out that the foremost task for a university is for students of different majors in different apartments to have the shared knowledge of a spiritual culture as the basics to study different professional knowledge (Hutchings, 1936). Students who choose to study different professional knowledge in one university, therefore, have to receive a common education, or liberal education. According to him, it is pointless and a great waste of money for students who study different majors with more and more specific specialization of work crowd in one modern university if it does not give them a common education, for they share almost nothing and have little in common. His great ambition and aim are to establish a four-year undergraduate school in Chicago University so that he could practice his liberal education by making students spend almost four years reading the classics. He worked out and delivered his plan but voted down. This repeated several times. In 1942, however, his plan finally got through and a system of a four-year undergraduate school aiming to strengthen liberal education was established in Chicago University, a modern 
research-based one. From then on, the undergraduate school in Chicago University was renowned for Hutchings School. Meanwhile, other universities like Harvard University and Yale University were trying hard to reform the way that liberal education was practiced in a fruitful way. After some time of reform and practice, the system of the undergraduate school in Chicago University changed to the first two years' liberal education and the rest two years' professional study (Zhang, 2007).

Klark Kerr, the former president of California University, pointed out, after his sum-up of the history of modern American higher learning, that the mode of the traditional British humanistic education restarted its influence upon American education during the 1920s and the 1930s after the impact from the German mode in the 19th century, and until the 1930s and the 1940s, the mode of American higher learning was finally made. This new mode was what was called by Kerr the mix of "the British Mode and the German Mode": the American undergraduate education inherited more from the British tradition, attaching more importance to undergraduate schools and undergraduate courses, and graduate teaching mode is German, giving priority to the development of graduate schools and professional schools.

\section{The Situation of American Undergraduate Schools}

The system of undergraduate school has been very well developed in the U.S., given the present development of the international higher learning. The quality of undergraduate schools was usually remarkably high, especially in those research-based universities. Undergraduate schools in the U.S. are also called College of Letters and Science or College of Arts and Science, but in Harvard University and Yale University, they are simply named Harvard College and Yale College. As to Chicago University, it is just called undergraduate school. The shared point of the educational pattern of undergraduate schools is that all the freshmen have to start their academic life in the undergraduate schools to study liberal education courses. In this pattern, some of the American undergraduate schools require their students to spend their academic life in the undergraduate schools in whole four years and some only one year for liberal education, while most of them choose to ask their students to spend the first two years in the undergraduate schools and the rest two years in the professional schools.

The more complicated was the American colleges of letters and science, for they are given the top priority in the universities. Some universities, like University of California, Berkeley, do not have the so-called undergraduate schools and all the students study in the colleges of letters and science or just in the professional schools. The colleges of letters and science are actually the undergraduate schools in this sense. But, what is different from Harvard College and Yale College that are specially designed for undergraduate education is that in the colleges of letters and science, post-graduates are usually enrolled and taught, and at the same time, arts and science post-graduate schools are established. But arts and science post-graduate schools usually do not do anything related with schooling and they only exist in the nominal sense, just like those post-graduate schools in mainland China. As a matter of fact, even in the undergraduate schools like Harvard College or Yale Collage, the teaching of the undergraduates is usually done by arts and science post-graduate schools. As the undergraduate schools are the principal carriers of liberal education in the U.S., liberal education is the most striking feature of the undergraduate schools and also the solid guarantee of the quality of the undergraduate education in these universities. In the survey A Report on the Harvard College Curriculum Research (Harvard University Team, 1945) made during the period of 15 months, one thing that has been made sure is that liberal education is the true nature of the undergraduate schooling. 
The teaching and management pattern of American undergraduate education almost makes no exception of adopting those of the undergraduate school or just College of Letters and Science. In Harvard University, Yale University, Stanford University, Princeton University, Columbia University, etc., all have the first-class undergraduate schools, and undergraduate education plays an irreplaceable role in these first-class universities. The reason why American undergraduate education has been able to break away from the binding of the sole teaching of professions and implement the idea of liberal education is that the management work of the undergraduates is done by a special organization, and the professional departments are just responsible for offering lessons and the teaching of graduates. Their undergraduates are not separated in the respective departments but grouped together to lead their academic life. Such a pattern of the management and teaching of American undergraduate schools has gradually taken shape, become an effective means, promoted the development of American higher learning, and updated students' global competitiveness (Li, 2011).

\section{Analyses of the Present Development and Situation of Undergraduate Schools in China}

The reform of American higher learning and the subsequent success of liberal education in the 1940s and the 1950s have had a great impact on the higher learning of the other countries across the world, especially mainland China that has been undergoing the reform of education and regions like Taiwan and Hong Kong. And the universities of China are now trying to draw lessons from the American educational reform.

\section{The Development and the Situation of Liberal Education in Taiwan and Hong Kong}

The first to practice liberal education in China are Taiwan and Hong Kong. In the 1950s and 1960s, in these two regions, liberal education was started and liberal education courses were given to the undergraduate students. In 1990, the first Liberal Education Center was established in Qing Hua University in Taiwan. It was actually just the same with the undergraduate school of the U.S. with all the functions of it. Until now, there have been 150 universities in Taiwan where liberal education centers or departments have been established. In view of the way liberal education runs in these universities, some centers or departments run in parallel with the other schools or colleges and some attach to the other schools or colleges, but have their own teachers, while the others are just the administrative offices with the full-time workers in charge of the schedule and management of liberal education, but their teachers are from other schools or colleges. The mode of teaching management of such liberal education centers or departments is that professional education usually goes in parallel with liberal education. With this mode, liberal education can be done when professional education is undergoing in the same academic year or even in the whole academic years, and there is no need for the students to have liberal education only in the first two years. The specific functions or duty of liberal education centers or departments, however, vary from university to university and do not run in the same pattern. The combination of professional education and liberal education, the continuing study of the idea of liberal education, the thoughtful design of the curriculum system, and the efforts made in the practice of liberal education, in general, all enable liberal education centers or departments to have developed into a very effective basis for liberal education (Jian, 2011).

\section{The Development and the Situation of Liberal Education in Mainland China}

The present situation of the development of undergraduate schools in some research-based universities. In the 21 st century, with the emergence of globalization of economic development and the global 
village, the competition between countries can be seen more and more in the vying over talents and at the same time the appeal to be geared to international conventions has been set on the high pitch. The higher learning which is being made internationalized has posed a great challenge to the reform of the mode of the Chinese higher learning. Some reputed research-based universities in mainland China took the lead in visiting the American universities to learn their approaches to practicing liberal education and their experiences drawing from the practices of liberal education.

With the ideas and experiences they got, these Chinese universities set out to establish undergraduate schools to practice liberal education. These newly-established schools are Fudan College in Fudan University (2005), Kuang Yaming Honors School in Nanjing University (2006), the former School for Intensive Instruction of Science and Arts (1998), Yuan Pei College in Beijing University (2007), Community College in Shanghai University (2007), the School of Truth in Zhejiang University (2008), the Undergraduate School in Zhongnan University (2010), the Undergraduate School in Harbin Institute of Technology (2011), Taishan College in Shandong University (2012), and so on. In the undergraduate schools like Fudan College, the School of Truth in Beijing University, Community College in Shanghai University, and the Undergraduate School in Harbin Institute of Technology, the mode of Freshman College is adopted, namely, in the first two years, liberal education is taught for students. These undergraduate schools are in the charge of the freshman schools-Academy of Classical Learning, but in the rest two years, they are under the charge of the professional schools when the students turn to professional studies.

Take the undergraduate schools of Fudan University and the like for example, Fudan College, Office of Teaching Affairs, Office of Undergraduate Recruitment, Center of Modern Educational Technology, Student Service Complex, and Textbook Center are integrated functionally into one body, affiliated with five accommodation academies of classical learning, including Zhide Academy, Tengfei Academy, Leqing Academy, Renzhong Academy, and Xide Academy. Fudan College takes charge of the student status management before the students go back to the professional schools to study one year later. The other schools, colleges, or departments have charge of the student status management when they come back for the professional studies. All the teachers of liberal education or of professions are chosen from different schools, colleges, or departments and accommodation academies of classical learning only have the charge of the second classroom development (Fudan University, n.d.).

The Undergraduate School of Zhejiang University ${ }^{1}$ has several offices and schools to its name as Office of Students' Affairs, Office of Teaching Affairs, Office of Teaching Research or Zhukezhen College, Office for the Quality of Teaching and Resources Management, and also School of Truth affiliated with three sub-schools. With the help of the professional schools, School of Truth takes charge of the student status management through the whole period of liberal education before they start to study their professions. Then the schools of professions take over the management after their professions are confirmed. But, not having their own teaching staff, they have to turn to the schools of professions for teachers, and their main task is to have charge of the second classroom.

The Undergraduate School of Harbin Institute of Technology ${ }^{2}$ consists of a School Office and the five other schools at the director's level: Office of Teaching Affairs, Office of Quality of Teaching and Resources

\footnotetext{
${ }^{1} \mathrm{http}: / /$ ugrs.zju.edu.cn/.

${ }^{2}$ http://hituc.hit.edu.cn/.
} 
Management, Office of Lab Management and Teaching Equipment, Talent School, and Department of Liberal Education. The student status management of the freshman is under the charge of Department of Liberal Education and later is taken over by the schools of professions. There are no teachers available in Department of Liberal Education and all of them are provided by the schools of professions or the departments of professions. The job of the enrollment of students is done by each college or school and is done so according to the different first-level disciplines, and there will be no sub-majors further divided. The students are entitled to decide their major fields from among the first-level disciplines and on graduation, they will receive diplomas of the first-level discipline majors.

The Community College in Shanghai University ${ }^{3}$ consists of Office of Teaching Affairs, Youth League Committee, Office of Enrollment and Job Advising, and Office of Education Quality Study and Evaluation. With all the offices in Community College cooperating with each other, an Enrollment Committee of Broad Category has been established. The Freshman Office in Office of Teaching Affairs takes charge of teaching management. The freshmen start and live their academic life in the Community College that has full charge of the student status management, and at the end of the first year, they will leave the Community College and be back at their respective colleges or schools where they will be put under the charge of respective collages or schools, and teachers of each college or school offer them teaching.

The mode in the development of undergraduate school which Zhongnan University and Shandong University adopt resembles that in management of a graduate school. By working together at the management level, they try to promote the development of liberal education, the first-level disciplines between colleges or schools, and the second classroom. The students' four-year academic life is under the full charge of respective professional colleges or schools.

The Undergraduate School of Zhongnan University ${ }^{4}$ has five offices: Coordination Office, Office of Students' Development, Office of Medical Teaching and Learning, Student Enrollment Office, and Office of Quality Education. The student status management is in the charge of respective professional colleges, schools, or departments. There are no professional majors given to the freshmen in the first academic year, but they will be given liberal education; in the sophomore year, they will be divided according to the majors they choose. Their teachers, then, will be provided by their respective professional colleges or schools. As to the student enrollment in this undergraduate school, they have practiced enrollment and subsequent teaching only at the level of disciplines since 2008 .

In the Undergraduate School of Shangdong University, ${ }^{5}$ there are Office of Teaching Affairs, Office of Teaching Research, Office of Test Management, Office of Teaching and Learning Practice, Office of Major Development and Field Operation, Office of Student Exchange, Office of Coordination, Office of Teaching Promotion and Teacher Development, Office of Undergraduate Enrollment, and Taishan College. Their student status management and teaching work are under the charge of respective colleges, schools, or departments. They also set up a school named Taishan School that undertakes the teaching work and the life of those top-notch students, and two years later, each of them will have two student status, but for them, Taishan School is only second to their professional school.

\footnotetext{
${ }^{3}$ http://residential.shu.edu.cn/Default.aspx.

${ }^{4}$ http://bksy.csu.edu.cn/.

5 http://www.bkjx1.sdu.edu.cn/default.site.
} 
Analyses of some of the undergraduate schools in mainland China. First of all, it is made clear that liberal education is implemented at the college or school level, and it is of great help, therefore, to enhance the implementation effect of liberal education as liberal education is practiced during the first-year period of study. Meanwhile, there is a clear target for the assessment and the check of the performance of liberal education implementation.

Secondly, after the whole year's study of the general knowledge in the undergraduate school, the students will go back to their professional colleges or schools to choose among the first-level disciplines according to what they are interested in and what they are good at and decide what majors they will study. This reform is effective and significant for the undergraduate schools due to the fact that the students are given more freedom in their choice of what knowledge they like or what they have to learn, so that what they learn will conform as close as possible to what they are interested in and consequently helps them improve efficiency of learning. It is, of course, a great challenge for the Four-in-One management mode of the teachers, tutors and counselors, seniors, and residence advisers in the undergraduate schools as to how to give the students their proper guidance on their choices of majors.

The newly formed undergraduate school has five functional offices that reinforce the means to organize the undergraduate teaching, places it at the same organizational level with the graduate teaching and upgrades the undergraduate teaching to a higher level.

It can be predicted that the above-mentioned universities like Beijing University or Fudan University will inevitably encounter difficulties in their development of undergraduate teaching, but how they will find solutions to settling them and continue their reform must be what the fellow teachers of the universities, the students, and the students' parents are most concerned about. Some economists concluded that China's continuous economic development after the open and reform attributes to the two factors: one is the technological advance - the imported technology and innovation - and the other is the transformation of manufacturing and business organizational forms or patterns. The reform of undergraduate schools can be regarded as the change of the organizational forms or patterns in the domain of education, or rather, a change of talent cultivation. We are full of anticipations that such a reform would promote the character development of the students in these universities and produce more talents to display their higher competitiveness the world over. It is also hoped that, by means of the reform, more highly-qualified scholars, technicians, and researchers generated by these Chinese universities would be recognized by the whole world.

\section{The Superiority and the Potential Problems in the Practice of Liberal Education in the Universities in Mainland China}

\section{Analyses of the Superiority of the Way of the Organization and Management of Undergraduate Schools}

The practice of liberal education in undergraduate schools will help put students first and accord top priority to promote students to develop in first-level disciplines with wide varieties of general basics and solid academic fundamentals. It is undoubtedly a most appropriate approach to collecting all the newly-enrolled students who intend to study different majors into the undergraduate schools to offer them the shared cultural knowledge. It is also a feasible way that the idea of putting students first or the student-centeredness could be practiced (The Joint Research Group of Tongji University, 2013).

By means of employing the undergraduate school to organize the teaching of liberal education, we may get a definite idea of what kind of professionals we will finally produce and what qualities they must have 
when they graduate. And with clear targets and expectations, we will be able to consider their frames of knowledge, intellectual development, moral values, humanistic attainment, and critical thinking ability, so that we can arrive at a final conclusion on in what proper way we can lay out the core curriculum system and improve the contents of courses.

It will help effectively utilize teacher resources and teaching materials, enhance the effective practical teaching, update the contents of the practical teaching, and strengthen students' innovation ability developed in the practice.

It will help turn out more talents with the individualized personality and globally-minded horizon, so that more innovative talents can be developed among the university graduates in the whole of China. All of them put under the charge of the same school-the undergraduate school studying different majors in different colleges or schools or different departments and taught the same materials, the students would be grounded in the basics of the spiritual culture. Such an environment will be able to highlight the creations of opportunities and accordingly help the students shape their individualized personality and boost their self-confidence. At the same time, it will help students understand and respect other cultures, strengthen their identification with their own culture, develop their globally-minded horizon, and motivate them to combine both their fervent aspirations and down-to-earth work, so that they may obtain the academic zeal for their studies in the later years. This will also help to secure or materialize the goal of the university managers who wish to have the first-class talents.

\section{Analyses of the Improvements Left to Be Desired in the Present Undergraduate Schools in Mainland China}

There are some incoordinations and incompatibilities between the enrollment of the students in the first-level disciplines across the schools or departments and the organizational systems of the schools or departments.

Through years of practice, the undergraduate schools in the universities mentioned above are still facing quite a few challenges, especially in the areas of enrollment and teaching. For instance, Fudan's undergraduate school is a system of academies. Most of the students believe that it can help them broaden their horizons, promote their understanding of the other disciplines, and expand their relationships with other students. But differences of different disciplines may generate unfavorable effects - those who major in physics complain that their course load is much heavier than that of those who major in Chinese. The teachers in the academies believe that it will help put liberal education into effect and promote the character development of the students. The fact, however, is that students will find that they are not so much attached to their majors when they set to work at their majors after a year of study in the academies. Meanwhile, the enrollment of the new students of Fudan University that took place in the majors of the first-level discipline across the schools or departments now has gradually developed into the one that takes place in the more specific majors, and it has actually been put under the charge of the schools or departments themselves.

There are some incompatibilities between liberal education and its practicality in Zhejiang University. The students select their own majors, but they are not so sure that they are able to decide finally to pursue what they have chosen, so some of them are compelled to wait a little longer to decide their majors. There are also other challenges the Undergraduate School of Zhejiang University has to meet. Due to the lack of the teachers who are able to teach or tutor them, more students tend to fail in their tests or exams and they feel they are not so much attached to their majors, and the managers of the school or department find that it is hard for them to handle such a situation. 
The Undergraduate School of Zhongnan University has met with such difficulties that there have been more and more offices and managers in the school and, as a result, there appear more barriers between offices and managers and the cooperation between them has become increasingly difficult. The situation may be very much the one where everybody's business is nobody's business. Some of the teaching staff and the students have misunderstood or even raised objections to the increasingly expanded offices and managers after the undergraduate school started to run. One reason for this is that it has increased the costs of the management and inevitably given rise to inconveniences.

In the development of the Community College of Shanghai University, there have appeared a series of challenges. The most obvious one is that the gap between favored majors and less favored ones has been further enlarged, but this situation has not met the desired goal for the development of majors. There are also other two challenges which may hinder the development of the undergraduate school. One is that the freshmen find that they are quite interested in their studies due to the fact that they are equipped with relatively more qualified teachers, but when they are sophomores, they feel disappointed at the learning atmosphere and that they are equipped with relatively less qualified teachers. The other is that in the first-year study, all the students, irrespective of their academic performance, stay together and they feel better, but after separation and when the students go back to their own schools or departments, it is found that what have been left are almost those with poor academic performance in a few schools or departments (The Joint Research Group of Tongji University, 2013).

There is much room left for the improvement of the system of the curriculum of the undergraduate schools. If the undergraduate school is regarded as the organizational form of liberal education, it follows that the development of the system of the curriculum of liberal education is the contents of the undergraduate school. But, due to the fact that there are different features of the universities, different histories of their development, and different beliefs and reforms that have been conducted in these universities, there appear, in their development, a series of problems like the structures of the curriculum that are not quite suited to the students, the numbers of the courses of liberal education that are not many enough, the quality of them that is not up to the standard, the highly-qualified teachers that are quite short of, the development of liberal education that is restricted by the current government policies, etc..

The joint developments of the first classroom where the students are taught by all the staff members of the school and the second classroom where the students are taught by the environment have met with difficulties. What the undergraduate school underscores is the improvement or enhancement of the students' originality, the making of their shared cultural basics, the promotion of their efficiency of the application of the new ideas in practice, and the development of their globally-minded horizon. Individual students, however, have their own peculiarity and complexity. Their character development has much to do with their family background, social environment, and the amount they are exposed to the outside world. The urgent need now is to find a possible solution to the problem of how to combine the courses in morality with the students' moral cultivation when they are learning the shared spiritual and cultural basics so that their character development will eventually be able to be promoted.

There is much to be desired in the patterns of organization and management of the undergraduate school. The undergraduate school is the carrier of liberal education and its core contents are the system of the core curriculum which may vary between universities depending upon their differences in category, history, mission statements, and distinctive features. But, as an organizer, the pattern of the undergraduate school has to be 
constant. The situation is that there are no constant and widely-recognized patterns, which has had some negative effects upon the aim or the development of liberal education.

\section{Measures and Suggestions for the Improvement of the Functions of the Undergraduate School}

\section{What Duties the Undergraduate School Must Do Ought to Be Clearly Defined}

This has to be considered in an all-round way the whole of the undergraduate students to handle the relevant issues:

1. The undergraduate school has to undertake the task of the students' moral cultivation and character development.

2. It has to draw up, put into practice, and improve the rules and regulations of the development of the students. Meanwhile, it has to manage the daily affairs relevant to teaching and try to make them run properly.

3. It has to undertake the tasks of the reform, research, and enhancement of the undergraduate teaching. These tasks include the design and the application of the curriculum of the undergraduate students, the compilation of the textbooks of the undergraduate students, the enhancement of the teaching ability of the teachers, and the promotion of the teaching research.

4. It has to undertake the task to ensure that the teaching and learning of liberal education must have better conditions and the quality of it must be under control. It must be responsible for keeping the teaching facilities in a good condition and the relevant technical supports available.

5. It has to undertake the establishment, control, and improvement of the system of teaching quality evaluation and tries to do a good job of it.

6. It has to undertake the management of the scientific research and its practice of the undergraduate students and also that of the science bases, so that it can put into the practice the plan of the development of the talents.

7. It has to take charge of the program schedules of the exchange students from both home and abroad and the student status management.

8. It has to try to remove the barriers between schools or departments, establish the special zone of the talents development, and cultivate top-notch talents.

9. It has to undertake the task of giving the graduates vocational guidance.

The Single Mode Should not Be Imposed Upon the Structure of Liberal Education Curriculum and It Must Be Specific or Proper to Different Undergraduate Schools With Different Characteristics and Categories

The fundamental purpose of liberal education is to seek what are the bare essentials and the perpetual constancy in any time and through any change. These essentials will be able to develop the essential ability of thinking that includes such things as the approaches to ethical issues, human life, and so on. The ultimate of liberal education is not only that it can be helpful to students in their cultivation of the original ideas and in their development of the innovative abilities, but that it will be able to provide an environment where the students can form a good habit of thinking deeply about anything they happen to learn and have an ambitious and insightful mind so that they, through years of study, will become men of independent personality, self-fulfillment, and great refinement. The present situation, however, is that universities in mainland China are not of the same type and they show different characteristics and diversified talents development objectives and 
the students tend to have different aptitudes. The universities, according to the development of knowledge in both scope and depth, can be divided into three categories: research-based, application-based, and vocation-based.

The main aim of the research-based universities is to develop the talents with academic research capabilities. But what they usually engage in is the teaching and research of the basic academic concerns. Their research in the relevant areas is generally in the lead among the other universities across mainland China, and they are in a position to undertake the governmental momentous projects of scientific research and innovation. Due to their research-based feature, the graduate education should be the priority among priorities, especially the doctoral education.

The majors of the application-based universities usually are designed according to the knowledge-based discipline categories. They usually do better in the teaching of undergraduate students. Their aim is mainly at developing professional talents, their target is primarily at particular professional sectors, and they are in a position to undertake the research projects of the central government and the local governments.

The majors of the vocation-based universities are usually designed according to the needs of the market. Their main aim is to develop the highly-qualified workers for the employers and their focus is mainly on the imparting of the skills and the ability of operation.

For the reasons mentioned above, it is necessary to form different expert groups to work out the core curriculum structure of liberal education suitable to different types of universities with different objectives, and it would be better for the authorities of the departments of education to organize and put it into practice.

\section{A Proper Mode of the Undergraduate Schools Should Be Formed According to Their Own Actual Situations or Distinctive Characteristics}

As universities of different types differ in such aspects as distinctive characteristics, objectives, purposes of their teaching, etc., they, therefore, have to establish the undergraduate schools suited to their own types. Take research-based universities for example, their mode of the undergraduate schools can be the one that puts students first, enroll students at the level of first disciplines, and offer them the general knowledge of shared cultural basics.

Specifically speaking, in the first-year study, the courses of liberal education, such as those of morality, military and physical training, foreign languages, and computer should be designed among all the first-level discipline majors. In the second-year study, the ABCs relevant to their majors should be designed under the first-level discipline majors. In the third-year study, the course module of academic frontier related to their majors should be designed in accordance with the needs of the society, the development of the disciplines, and the needs of the professional study. In the fourth-year study, the course module, applicable and practicable, should be designed with flexibility and variety in accordance with the needs of the society, their future occupation, and their further study. More optional courses should be offered to meet the needs of the personal development. In addition, the management mode can be the combination of the decentralized one by the undergraduate school itself and the centralized one by the executive body of the university.

\section{Specific Measures to Bring Undergraduate Schools Into Effect by Employing Practical and Effective Means Should Be Taken}

A practical and an effective decision-making system should be developed. Such bodies as the committee in charge of the whole affairs of the school or the joint-conference- the top policy-maker, the 
steering committee of teaching, the working committee in charge of the students' character development and their awards and punishments, and the supervising committee of teaching should be established. The later three committees are respectively the adviser, the supervisor, and the executer of the committee in charge of the whole affairs of the school.

A curricular module should be worked out. It is necessary that the core curricula be worked out with the belief of the sustainable development of liberal education by sorting and integrating the modules built in the four years - the liberal education module, the first-level discipline module, the module of the professional theory and the practical teaching, and the module of personalized development.

The system and mechanism of the security of the teaching facilities and quality control should be established. The system and mechanism of the security of the teaching facilities and quality control should be established, so that the supply and maintenance of the teaching facilities and the relevant technical support can be available. After the evaluation system of the quality of the teaching is established, they should supervised and improved or updated. The whole of the evaluation work must be very well done.

The management system for the daily affairs of the undergraduate school and its operating mechanism should be established. The system of the regulations and rules for developing the undergraduate students should be worked out, and then it must be put into effect and improved or updated. The teaching of the undergraduate students and the daily management of the teaching affairs must be put into effect and kept in proper order. The guidance of the choice of the would-be careers of the students should be provided.

The research institutions of the teaching reform and development should be established and improved. Teacher training should be strengthened, the design of the curricular module should be improved, and the compilation and writing of the textbooks should be given more importance, so that the goal of the development of outstanding talents can be achieved. In addition, universities can establish a special-zone college according to their own characteristics and development goal. Meanwhile, an interactive mechanism between the teacher and the students should be put into effect and the mechanism of the teacher and the counselor in charge of the students' academic life who enter into the students' spare time or into their dormitory should be established.

\section{Conclusion}

As a mode of liberal education, an undergraduate school being carried out in modern universities is but an inevitable choice. It goes without saying that, compared with other modes of the talent training like the British Mode and the German Mode, it has relatively met more of the needs of the social development and the requirements of the talents training, although the training mode itself has a lot to be desired. It has been more than a century since literal education originated in the universities of the U.S., Chinese universities, however, have started their practices of liberal education only in the recent years. What the Chinese universities has to do is that, by drawing lessons from those of the other countries and the regions outside mainland China, they have to work out their own approaches to running undergraduate schools for liberal education that fit their own actual situations and their own characteristics.

\section{References}

Fudan University. (n.d.). The education of the undergraduate students of Fudan University. Retrieved from http://www.fudan.edu. $\mathrm{cn} /$ channels/view/49/

Gan, Y. (2007, December 20). The possibility of liberal education in the universities of China. Tianyi Lecture. 
Hutchings, R.M. (1936). The higher learning in America. New Brunswick, N.J.: Transaction Publishers.

Jian, Z. F. (2011). Research of the setting of the entity institution of the liberal education of universities. Hubei Social Science, 8 , 172-174.

Li, W. J. (2011). The emergence of the undergraduate school. Education and Vocation, 1, 6.

The Joint Research Group of Tongji University. (2013). The information on the investigation and research of some of the undergraduate schools both at home and abroad. Shanghai: The Joint Research Group of Tongji University.

Undergraduate School. (n.d.). In Baidu Baike. Retrieved from http://baike.baidu.com/link?url

$\mathrm{Xu}, \mathrm{X}$. F. (2014). Reform and innovation of computer education under the system of the undergraduate school. University Teaching of Mainland China, 4, 20-22.

Zhang, X. G. (2007). References of liberal education. Retrieved from http://wenku.baidu.com/view/35039837f111f853d05 abf.html 